\title{
Items of Tributary Gifts (Pangmul 方物) Sent to the Ming Dynasty by Chosŏn and their Changing Trends
}

\author{
Doyoung Koo*
}

\section{Introduction}

Diplomacy between Chosŏn Korea (朝鮮; 1392 1910) and Ming China (明; 1368 1644) was carried out via envoys. Chosŏn envoys traveled to Beijing to hand over diplomatic documents and discuss state affairs. These envoys also presented 'tributary gifts' (pangmul / 方物) to the Ming imperial court and received some in return. ${ }^{1}$ The Chosŏn court paid particular attention to the composition of pangmul. Given the significance of these ritualistic diplomatic exchanges, pangmul were usually selected with care and made up of Chosŏn specialty goods. This paper explores how the type and quantity of goods included in Chosŏn pangmul reflected both the economic situation of the time and diplomatic relations between the Chosŏn and the Ming.

Before diving deeper, it is important to understand the different types of diplomatic envoys. Every year, the Chosŏn dynasty regularly dispatched chŏngjosa 正朝使 (or tongjisa 冬至使), sŏngjŏlsa (聖節使), and ch'ónch'usa (千秋使). Chŏngjosa were delegations sent to celebrate the Lunar New Year, seongjeolsa were sent to celebrate the emperor's birth-

\footnotetext{
* Research Fellow at the Northeast Asian History Foundation.

1 Shen Shixing, Daming Huidian, 116.
} 
day, and ch'ónch'usa were sent to celebrate the crown prince's birthday. ${ }^{2}$ Of these, ch'onch'usa were rather rare since Ming princes were rarely proclaimed as heirs to the throne. The Chosŏn dynasty also dispatched envoys to deal with specific diplomatic matters such as the saŭn (謝恩), chinha (進賀), and chumun (奏聞). These envoys also brought pangmul to the emperor, empress, etc.

Most studies of Chosŏn-era pangmul focus on detailed information on regular envoys given in the Veritable Records of the Chosŏn Dynasty (朝 鮮王朝實錄), a document from $1430 .{ }^{3}$ Because most studies have focused on this document, research focuses primarily on early 15 th-century pangmul. There are no studies that have examined the pangmul presented to the Ming dynasty by the regular envoys of Chosŏn in the 15th and 17th centuries. ${ }^{4}$ Other than these studies, studies have confirmed the types of fabrics included in pangmul ${ }^{5}$ and reviewed the quantity of ginseng in regular and special dispatches. ${ }^{6}$ This has led previous studies to accept that the basic tone of Chosŏn-era pangmul policy established in 1430 continued until the end of the Ming dynasty in the mid-17th century and overlook changes in these policies over time.

This paper attempts to fill this gap in the literature by comprehensively examining trends in the composition of Chosón-era pangmul to the Ming between the 15th and 17th centuries. It tracks changes in the types and quantity of pangmul given by regular envoys to the emperor and explores the meaning of the inertia and change we can observe in the presentation of pangmul over this period. It also includes a qualitative discussion of the characteristics of pangmul - a novel approach in the literature, which has largely focused on itemizing tributary offerings. This approach allows

2 From 1531 (26th year of King Chŏngjong), Chŏngjosa was changed to Tongjisa to celebrate Tongji—winter solstice (Doyoung Koo, 2013).

3 Shin Sŏkho (1959); Kim Kujin (1990); Yoo Seungjoo (1989); Koo (2013).

4 Changes in the quantity between the 15 th and 17 th centuries were examined only for ginseng among the tributary gifts (Koo, 2020).

5 SimYeonok and Keum Jongsuk (2013).

6 Park Pyeongsik (2008). 
this paper to analyze how pangmul reflect Chosŏn-Ming relations and other historical contingencies, such as the effects of the Japanese invasions of 1592 (also known as the Imjin Wars) and the Chosŏn dynasty's economic recovery from the war.

This paper proceeds as follows. First, it examines 15th- and 16thcentury pangmul. It verifies the contents of pangmul given before and after 1430, when Chosŏn policy changed, and explores the quantity and commercial value of these pangmul. Second, it explores how the Imjin Wars changed the goods selected for pangmul. Although the details of regular envoys' pangmul are rarely recorded in the Veritable Records of the Chosŏn Dynasty, the diplomatic documents between 1592 and 1608 are included in sadaemun'gwe (事大文軌). This paper uses this source to examine pangmul given after the Imjin Wars and, thus, examine the effects of the war in general.

This paper has the significance of research in the following aspects. First, by extending the history of pangmul of Chosŏn (where analysis has previously stopped at the 15th century (1430)) to the first half of the 17th century, the long-term trend of pangmul (about 250 years) as connected to the Chosŏn and Ming relationship can be confirmed. Second, this paper can confirm changes in the management of pangmul in Chosŏn according to the flow of times, and confirm the diplomatic methods and characteristics of Chosŏn toward the Ming Dynasty. Third, it is possible to check how the representative products of Chosonn changed according to the time, and to find their economic meaning.

\section{5th- and 16th-Century Pangmul}

The Koryŏ (高麗; 918 1392) government decided on the items and quantities of pangmul that it sent to the Khitan (契丹/遼; 916 1125) and the Jin (金; 1115 1234). Since pangmul were a gift, such policies was not decided unilaterally by China but were instead made in the spirit of 
Koryŏ's sincere tribute. ${ }^{7}$ We can surmise that the Chosŏn dynasty partially inherited the pangmul practices of the Koryŏ-Ming era (1368 1392) because their diplomatic practices followed those of the Koryo dynasty. During the Koryŏ era, pangmul consisted of gold and silver sent to the Khitan (Liao), Jin, Yuan, and Ming dynasties, ${ }^{8}$ while Chosŏn tried not to send gold and silver from the time of King T'aejong (太宗; r. 1400 1418). If the Chosŏn dynasty had redefined a new policy on tributary gifts after its founding, it would not have included gold and silver in the items. As will be described later, the gold and silver, colorful mats, ramie fabric, leopard skin, and otter skin sent by King Kongmin (恭壂王 r. 1351-1374) of Koryŏ to the Ming are similar to those of Chosŏn. ${ }^{9}$

In the Daming Huidian (大明會典), pangmul sent by the Chosŏn dynasty to the Ming dynasty are recorded. It is divided into two editions - the Zhèngdé huidiăn, compiled during the late 15 th and early 16th centuries, and the Wànlihuidiăn, compiled at the end of the 16th century. The former states that early Chosŏn pangmul included gold and silver tableware (金銀器孟), multi-colored ramie (各色苧布), white figured mats (白細花 席), ginseng (人參), leopard skin, otter skin, weasel-tail hair writing brushes (hwangmop'il 黃毛筆), and high-quality white paper (paekmyŏnji 白綿紙). ${ }^{10}$ The Veritable Records of the Chosŏn Dynasty gives us some more detail here. For example, in 1401 (the first year of King T'aejong's reign), Chosŏn saŭn envoy gave Jiànwén Emperor (建文帝) 50 horses, four gold saddles, 200 pil (匹) of hemp-ramie, and 80 pil of hemp-ramie to the empress. ${ }^{11}$ These were simple pangmul for an irregular occasion. In contrast, in August 1419 (the first year of King Sejong's reign), envoys took a more diverse variety of gifts - white fine ramie, black fine hemp,

7 Jung Donghun (2018).

8 Koryŏsa 20:14 (Aug. 16, 1321); Koryŏsa 24:57 (Jun. 18, 1374); T'aejo Sillok, 29:17 (Dec. 12, 1388); Jung Donghun (2018).

9 Koryŏsa 24:57 (Jun. 18, 1374).

$10 \mathrm{Xu} \mathrm{Pu}$, Daming Huidian, fasc. 97, tribute 2, Chosŏn.

11 T'aejong Sillok, 1:35a (Jun. 19, 1401). 
silk and hemp blended tabby fabrics, silk and ramie blended tabby fabrics, yellow-featured mats, various color-featured mats, featured blinds and mats, various featured woven cushions, colorful featured mats, ginseng, stone lanterns, weasel skin, and a variety of colored horses. ${ }^{12}$ These records both indicate that at the beginning of the Chosonn dynasty there was no fixed policy for pangmul given by irregular envoys and that these pangmul were seen as significant enough that records of them were kept. The composition of irregular envoys' pangmul were relatively flexible and changed to suit the occasion.

The earliest source that can clearly confirm the contents of regular envoys' pangmul is an article from 1430, contained in the Veritable Records of the Chosón Dynasty. This document describes pangmul given by chŏngjosa, sŏngjŏlsa, and ch'önch'usa to the Ming Emperor, Empress, Empress Dowager, and Crown Prince. There is no historical record of the items and quantities of regular envoys' pangmul in the early Chosŏn dynasty, in part because the relevant policies changed dramatically during this time. ${ }^{13}$ In 1429, King Sejong's court asked the Ming if it could exclude gold and silver from its pangmul and the Ming accepted. ${ }^{14}$ The Chosŏn court included various specialty items as substitutes for these precious metals. These are included in the Veritable Records after 1430 and listed in Table 1 below.

Table 1 emphasized changes in the quantity or character of items given as pangmul in bold face. The table can help us better comprehend changes in the quantity of pangmul given by regular envoys before and after 1430; specifically, it can help us determine which items were included as substitutes for gold and silver and, thus, considered representative or specialty products of the Chosón dynasty. Let us take a more detailed look at these

12 Sejong Sillok, 5:9a (Aug. 25, 1419).

13 T'aejong Sillok, 17:4b (Jan. 21, 1409); T'aejong Sillok, 12:11a (leap month of Jul. 18, 1406); T'aejong Sillok, 17:35a (leap month of Apr. 28, 1409); Sejong Sillok, 7:12b (Jan. 25, 1420).

14 Sejong Sillok, 45:14a (Aug. 18, 1429); Sejong Sillok 46:18a (Dec. 13, 1429). 
items, one by one.

Table 1. Changes in the list of tributary gifts of the Chosŏn dynasty before and after 1430

\begin{tabular}{|c|c|c|c|c|c|c|c|c|c|c|c|c|c|c|c|c|c|}
\hline \multirow{3}{*}{\multicolumn{2}{|c|}{ As o }} & \multicolumn{8}{|c|}{ Chŏngjo (tongji) } & \multicolumn{6}{|c|}{ Sŏngjŏl } & \multirow{2}{*}{\multicolumn{2}{|c|}{$\begin{array}{l}\begin{array}{l}\text { Ch' ŏn- } \\
\text { ch'u }\end{array} \\
\text { Crown } \\
\text { prince }\end{array}$}} \\
\hline & & \multicolumn{2}{|c|}{ Emperor } & \multicolumn{2}{|c|}{ Empress } & \multicolumn{2}{|c|}{\begin{tabular}{|l|} 
Empress \\
dowager
\end{tabular}} & \multicolumn{2}{|c|}{$\begin{array}{l}\text { Crown } \\
\text { prince }\end{array}$} & \multicolumn{2}{|c|}{ Emperor } & \multicolumn{2}{|c|}{ Empress } & \multicolumn{2}{|c|}{$\begin{array}{l}\text { Empress } \\
\text { dowager }\end{array}$} & & \\
\hline & & $\begin{array}{l}\text { Be- } \\
\text { fore }\end{array}$ & $\begin{array}{c}\text { Af- } \\
\text { ter }\end{array}$ & $\begin{array}{c}\mathrm{Be}- \\
\text { fore }\end{array}$ & $\begin{array}{l}\text { Af- } \\
\text { ter }\end{array}$ & $\begin{array}{l}\text { Be- } \\
\text { fore }\end{array}$ & $\begin{array}{l}\text { Af- } \\
\text { ter }\end{array}$ & $\begin{array}{l}\mathrm{Be}- \\
\text { fore }\end{array}$ & $\begin{array}{c}\text { Af- } \\
\text { ter }\end{array}$ & $\begin{array}{l}\text { Be- } \\
\text { fore }\end{array}$ & $\begin{array}{c}\text { Af- } \\
\text { ter }\end{array}$ & $\begin{array}{c}\text { Be- } \\
\text { fore }\end{array}$ & $\begin{array}{l}\text { Af- } \\
\text { ter }\end{array}$ & $\begin{array}{l}\text { Be- } \\
\text { fore }\end{array}$ & $\begin{array}{l}\text { Af- } \\
\text { ter }\end{array}$ & $\begin{array}{l}\text { Be- } \\
\text { fore }\end{array}$ & $\begin{array}{l}\text { Af- } \\
\text { ter }\end{array}$ \\
\hline \multirow{6}{*}{$\begin{array}{l}\text { Textile } \\
\text { (Unit: pil) }\end{array}$} & yellow ramie & \multicolumn{2}{|c|}{10} & & \multicolumn{2}{|l|}{. } & \multicolumn{2}{|r|}{-} & \multicolumn{2}{|c|}{10} & \multicolumn{2}{|l|}{-} & \multicolumn{2}{|c|}{-} & \multicolumn{2}{|r|}{ - } \\
\hline & white ramie & \multicolumn{2}{|c|}{20} & \multicolumn{2}{|c|}{20} & \multicolumn{2}{|c|}{20} & \multicolumn{2}{|c|}{15} & \multicolumn{2}{|c|}{20} & \multicolumn{2}{|c|}{20} & \multicolumn{2}{|c|}{20} & 16 & 20 \\
\hline & red ramie & \multicolumn{2}{|c|}{-} & \multicolumn{2}{|c|}{10} & \multicolumn{2}{|c|}{10} & \multicolumn{2}{|r|}{ - } & - & - & 10 & & 10 & & & - \\
\hline & Hemp & 20 & 40 & - & 30 & - & 30 & & 15 & 20 & 70 & -1 & 40 & - & 40 & 16 & 60 \\
\hline & $\begin{array}{c}\text { Ramie and } \\
\text { hemp blended } \\
\text { tabby }\end{array}$ & - & - & - & & - & & & - & 1 & $\mathbf{0}$ & - & & - & & - & - \\
\hline & Mо̆nju & & 20 & - & 10 & - & 10 & - & 10 & - & 20 & - & 10 & - & 10 & 1 & 10 \\
\hline & Manhwasŏk & 20 & 0 & 8 & 10 & 8 & 10 & 2 & 10 & - & - & 7 & 10 & 7 & 10 & 10 & 15 \\
\hline & Yŏmsŏk & - & & - & & - & & & - & 2 & 2 & - & & - & & - & - \\
\hline $\begin{array}{l}\text { Mats } \\
\text { (Unit: }\end{array}$ & $\begin{array}{c}\text { Makhwabang- } \\
\text { sǒk }\end{array}$ & & 20 & - & & - & & 5 & 10 & 10 & 20 & - & & - & & 10 & 15 \\
\hline ang) & $\begin{array}{l}\text { Hwanghwa- } \\
\text { sók }\end{array}$ & 10 & 20 & - & 10 & - & 10 & & 10 & 10 & 20 & 10 & & 10 & & - & 5 \\
\hline & Ch'aehwasŏk & 10 & 20 & 10 & & 10 & & & 10 & 10 & 20 & 10 & & 10 & & 1 & 0 \\
\hline Medicinal & Ginseng $(k \breve{u} n)$ & 50 & & - & & - & & 20 & 40 & 5 & 0 & - & & - & & 20 & 40 \\
\hline $\begin{array}{l}\text { Small } \\
\text { furniture }\end{array}$ & $\begin{array}{l}\text { Small mother- } \\
\text { of-pearl boxes }\end{array}$ & - & & 1 & & 1 & & & - & & & - & & - & & & - \\
\hline Skins & Leopard skin & 10 & & - & & - & & & 6 & 1 & $\mathbf{0}$ & - & & - & & 6 & 6 \\
\hline $\begin{array}{l}\text { (Unit: } \\
\text { chang) }\end{array}$ & Otter skin & - & & - & & - & & & - & 2 & $\mathbf{0}$ & - & & - & & 1 & 0 \\
\hline Stationery & $\begin{array}{l}\text { Weasel-tail- } \\
\text { hair brushes }\end{array}$ & - & & - & & - & & & - & & & - & & - & & 2 & 20 \\
\hline Horses & Horses & & 30 & - & & - & & - & 4 & & 40 & - & & - & & - & 10 \\
\hline
\end{tabular}

Source: Sejong Sillok, 47:23b (Feb. 26, 1430); Sŏngjong Sillok, 274:12b (Feb. 27, 1493) 
Ramie (苧布)

The majority of pangmul were fabrics and mats. Ramie (moshi in Korean) - an expensive Chosŏn textile - was the most common kind of fabric included here. In the 16th century, one pil of ramie was worth as much as 10 pil of cotton cloth. ${ }^{15}$ Chosón's ramie was called sejŏp'o because the strand was very thin and required a great amount of effort to weave it. ${ }^{16}$ In 1577, an eminent Ming official suggested that because Chosŏn's "white ramie and yellow ramie are thin and durable, they are much better than those of southern China." The textile of Chosŏn ramie was inevitably as fine as it was thin, and it was also remarkably durable.

Hemp (麻布)

In 1430, the most added fabric was hemp. Hemp was the most widelycollected good that the Chosŏn court collected as a tax from its people. The Sejong Sillok Chiriji (世宗實錄地理志) indicates that hemp was the most widely-produced fabric of 15 th-century Chosŏn. ${ }^{17}$ The quality of hemp was classified according to the fineness of the strand. For instance, the Chosorn court collected a tax of "the hemp with fineness of the strand" (osŭngp'o 五升布). This was official cloth, called chŏngp'o (正布). When visiting Chosŏn in 1488, the famous Ming envoy Dong Yue (董越) observed, "Ordinary people wear many hemp clothes in layers. The clothes are usually white and thick" and that their "elaborate hemp clothes are thin and dense like silk." 18 This anecdote indicates that both loose and fine hemp were available and popular in the Chosón dynasty, ${ }^{19}$ and that

15 Myŏngjong Sillok, 2:93a (Nov. 17, 1545).

16 Hakpong Ilgo and Choch'ón Ilgi, May 1, 1577.

17 Cho Sangjun (2020).

18 Dong Yue (2012).

19 Sejong Sillok, 1: 18a (Sept. 8, 1418); Sejo Sillok 1:25b (leap month of Jun. 29, 1455); Sŏngjong Sillok, 52: 7a (Feb. 8, 1475). 
the hemp sent to the Ming's imperial family was fine-quality hemp. ${ }^{20}$ The Chosŏn people customarily called hemp "black hemp," but its actual color was yellow, not black. ${ }^{21}$

\section{Tabby Silk (Myŏnju 綿紬)}

Myŏnju was added to pangmul in $1430 .{ }^{22}$ It was soft to the touch, but it was a silk fabric with little gloss and no pattern. Ming Chinese silkmaking techniques were advanced enough to weave saranŭngdan (紗羅綾 緞), a high-quality silk fabric; by contrast, Chosŏn weavers only weaved middle-grade silk. High-ranking Chosŏn nobles mostly wore myŏnju. The quality of Chosŏn myŏnju was excellent. ${ }^{23}$ This is further proven by the fact that the Ming Emperor was also interested in nokchiǔi (綠紬衣), a dyed-green silk fabric, and ordered it to be procured by the envoy Zheng Tong (鄭同). ${ }^{24}$

\section{Mats (sŏk 席)}

There were five types of mats: manhwasŏk (滿花席), manhwabangsŏk (滿花方席), hwanghwasŏk (黃花席), ch'aehwasŏk (彩花席), and yŏmsŏk (策席). The “flower" ( $h w a$ 花) character is in the name here and connotes a colorful pattern, not a flower pattern. ${ }^{25}$ The manhwasŏk, hwanghwasŏk, and ch'aehwasǒk of mats were floor mats classified by pattern and color. The manhwabangsŏk was a single-person mat. Yŏmsŏk was a window blind. Mats were important because the Chosonn people mainly sat on the

20 Hakpong Ilgo and Choch'ón Ilgi, May 1, 1577.

21 Hakpong Ilgo and Choch 'ŏn Ilgi, May 1, 1577.

22 Kosach'waryo, Mallyŏk (Wanli) Year 9 (14th year of King Sŏnjo).

23 Cho Hyosook and Lee Eunjin (2011).

24 Yejong Sillok 4:16b (leap month of Feb. 24, 1469).

25 Through the Chosŏn dynasty portraits, one can see the various mat patterns, including the dragon, tiger, ten longevity symbols, lotus, and various geometric patterns (Kim Sunghee, 2017). 
floor without chairs. More elaborate mats were laid on the bed or living room floor, and rough mats were used for laying on the ground. ${ }^{26} \mathrm{By}$ contrast, Ming people sat on chairs; therefore, mats were not as culturally important. ${ }^{27}$ This made Chosŏn mats a specialty item and an item of interest. $^{28}$

\section{Ginseng}

Ginseng was originally sent in the following denominations: $50 \mathrm{kun}$ (each kŭn is estimated to be 400 grams) to the emperor and $20 k \breve{u n}$ to the crown prince. After gold and silver were removed from pangmul, the amount of ginseng given to the crown prince increased by $40 \mathrm{kŭn}$. Since there always was an emperor but there was only a crown prince when the emperor designated one of his sons as the heir, about half the period of the Ming dynasty. ${ }^{29}$ Therefore, the decision to add ginseng only to the crown prince was effective in reducing the amount of ginseng sent as pangmul.

Animal skins

Animal skins, such as leopard and otter skins, were a common feature of pangmul. The quantity of these skins did not increase in 1430 and skins represented only a small portion of pangmul. Around 1448, the price of leopard skin was about 50 times more expensive than otter skin. ${ }^{30}$ In Chosŏn, the price of leopard skin was higher than that of tiger skin. The value of these skins can also be seen in the fact that, from its founding, the Chosŏn court forbade some pangmul items (including leopard and

26 Xuanhe Fengshi Gaoli Tujing, Kongjang 1, a figured mat.

27 Hakpong Ilgo and Choch'ŏn Ilgi, May 1, 1577.

28 Chungjong Sillok 100:63b (May 8, 1543).

29 Koo, 2020.

30 Sejong Sillok, 122: 2a (Oct. 8, 1448). 
otter skins) to be exported privately to foreign countries. ${ }^{31}$

Weasel-tail hair writing brushes (hwangmopil 黃毛筆) and horses

Hwangmopil, or brushes made of weasel hair, was added to pangmul in 1430. The Chosonn dynasty sent 20 such brushes to the Ming crown prince on his birthday each year. Horses were also added in 1430. Horses were expensive, but less difficult or dangerous to procure than gold or silver. ${ }^{32}$ In particular, there was a power struggle between the Jiànwén Emperor (建文帝; r. 1398 1402) and Yǒnglè Emperor (永樂帝; r. 1402 1424) in the early days of the Ming. The Ming also needed horses to sustain its conquest of Mongolia, so they were seen as valuable for both sides. Therefore, the Chosŏn government decided that horses were appropriate to replace gold.

In short, Chosŏn pangmul to the Ming in the early 15 th century reflected the economic and diplomatic situation of the time. Although the Chosŏn dynasty inherited the diplomatic conventions of the Koryŏ era, the Chosŏn kings changed the nature of pangmul by emphasizing a people-first principle and removing gold and silver from pangmul. Items that were added to pangmul after 1430 were easy-to-get goods, specialty goods, or useful resources such as horses; extremely rare, valuable, or difficult-to-obtain items like animal skins were not added to the list.

The Chosŏn dynasty laboriously prepared tributary gifts, which they had to present to the Ming while preserving their quality. In light of this, packaging was important. The regulations regarding packaging for tributary gifts specified the following. First, items had to be sealed using oil paper. ${ }^{33}$ To prevent items from getting wet through exposure to rain or

31 Kyŏngguk Taejŏn, Criminal Codes and Prohibited Articles. In addition to leather, exports of mats and papers were also restricted.

32 Kim Soonja (2000).

33 Sejong Sillok, 64:4b (Apr. 9, 1434). 
water, they were tightly packed in oil paper bags in summer, ${ }^{34}$ whereas beeswax wrapping cloth was used in winter when it was drier. Next, tributary gifts were wrapped again in oil seats. ${ }^{35}$ To wrap the gifts, thick oil paper, oil packaging bags, fur coat leather, and oil seats were largely used. After the Imjin Wars in the late 16th century, it was difficult to secure thick oil paper and oil packaging bags, so they invented the method of placing tributary gifts in a wooden box, wrapping it with cloth, and then coated in bitumen. ${ }^{36}$ The importance of packaging was emphasized by allowing all major vassals and ministers to attend the packaging process. ${ }^{37}$ As we can see from Table 1, the provisions of regular envoys' pangmul regular gifts and the quantities continued into the 16th century.

\section{Changes in Pangmul during and after the Imjin Wars (壬辰倭亂 1592-1598)}

The Imjin Wars destroyed daily life in the Chosŏn dynasty. The king left the capital of Hanyang and took refuge in the north, collecting taxes was infeasible, and, thus, it was difficult for the Chosonn court to coordinate and prepare pangmul to the Ming. We can glimpse the situation in an article from February and March 1594, two years after the war began:

The Ministry of Revenue (hojo 戶曹) said, “There are only three manhwasŏks and four ch'aehwasŏks in the national warehouse of changhŭng (changhünggo 長興庫), and only one skin and 10 ginseng roots in the changhünggo, and nothing else. Even

34 Sŏngjong Sillok, 238:2b (Mar. 4, 1490); Sŏngjong Sillok, 239:6b (Apr. 15, 1490).

35 Sŏngjong Sillok, 282: 8a (Sept. 5, 1493).

36 Sŏnjo Sillok, 200: 20a (Jun. 20, 1606). Yǒkch'ŏng is natural asphalt or tar, which was used as waterproofing paint.

37 T'aejong Sillok, 6:24b (Nov. 2, 1403); Chungjong Sillok, 17:4a (Oct. 10, 1512). 
if it is set in half, there is no way to prepare..."38

The Ministry of Rites (yejo 禮曹) said, "It would be appropriate to send the specified number of horses to this sŏngjŏlsa, but during the war, the horses were very emaciated because the proper number of horses was insufficient, and they could not be raised in advance as usual. Death on the way and incurring losses will surely be doubled than before." 39

These quotes indicate that the Chosŏn treasury and stock of horses were both depleted due to the war. As the war wore on, the Chosón court sought to maintain its diplomatic relations with the Ming by including items in pangmul that could be secured more easily under the stressful wartime conditions. ${ }^{40}$ It did not resort to exploiting the people when preparing the emperor's pangmul. We can examine this deeper after considering Table 2, which lists pangmul sent to the Ming Emperor by the sŏngjŏlsa in June 1593.

Table 2 indicates relative changes in the quantity of goods supplied in pangmul before and after the Imjin Wars. The table indicates that the Chosŏn dynasty endeavored in vain to sustain the existing pangmul system as much as possible but could not. Textiles suffered the biggest blow: yellow ramie, hemp, myŏnju could not be procured at all. They secured only white ramie among the textiles. The pangmul of 1593 contained about half the mats, half the horses, and one-fifth the animal skins of prewar pangmul. New gifts were prepared in their place. These include two

38 Sŏnjo Sillok, 48:27a (Feb. 22, 1594) “戶曹啓曰聖節使進獻可合之物 長興庫 只有滿花席三張彩花席四張 濟用監只有豹皮一張人參十斤 餘皆無有 折半定數 萬無措備之路.”

39 Sónjo Sillok, 49:2a (Mar. 2，1594) “禮曹啓曰 今次聖節貢馬 所當量宜封進 而賊變之後 非但可合之馬 厥數不敷 且不得依平時前期預養 瘦亦甚 中路倒損 必倍於前.”

40 Sŏnjo Sillok, 49:2a (Mar. 2, 1594); Sŏnjo Sillok, 127:24b (Jul. 16, 1600). 
Table 2. List of Sŏngjŏlsa envoys’ Pangmul for the Ming Emperor (1593).

\begin{tabular}{|c|c|c|c|c|}
\hline $\begin{array}{l}\text { Type of } \\
\text { items }\end{array}$ & Pangmul & $\begin{array}{l}\text { Before the } \\
\text { Imjin Wars }\end{array}$ & Year 1593 & $\begin{array}{l}\text { Relative } \\
\text { increase or } \\
\text { decrease }\end{array}$ \\
\hline \multirow{5}{*}{ Textiles } & Yellow ramie & 10 & 0 & -10 \\
\hline & White ramie & 20 & 20 & 0 \\
\hline & Hemp & 70 & 0 & -70 \\
\hline & $\begin{array}{l}\text { Ramie and hemp blended } \\
\text { tabby }\end{array}$ & 10 & 0 & -10 \\
\hline & Myо̆nju & 20 & 0 & -20 \\
\hline \multirow{4}{*}{ Mats } & Yŏmsŏk & 2 & 2 & 0 \\
\hline & Manhwabangsŏk & 20 & 5 & -15 \\
\hline & Hwanghwasŏk & 20 & 8 & -12 \\
\hline & Ch'aehwasŏk & 20 & 20 & 0 \\
\hline Medicinal & Ginseng & 50 & 50 & 0 \\
\hline Horses & Horse & 40 & 20 & -20 \\
\hline \multirow{3}{*}{ Skins } & Leopard skin & 10 & 2 & -8 \\
\hline & Otter skin & 20 & 5 & -15 \\
\hline & Tiger skin & - & 2 & +2 \\
\hline Fans & Folding fan(白扇) & - & 100 & +100 \\
\hline \multirow{5}{*}{ Stationery } & Kyŏngmyŏn paper(鏡面紙) & - & 40 & +40 \\
\hline & Paekmyŏn paper（白綿紙） & - & 400 & +400 \\
\hline & Hwangmopil (黃毛筆) & - & 100 & +100 \\
\hline & Inkstones (hwayŏn 畫硯) & - & 2 & +2 \\
\hline & $\begin{array}{l}\text { Genuine ink stick } \\
\text { (chinmuk 眞墨) }\end{array}$ & - & 100 & +100 \\
\hline
\end{tabular}

* Units of existing tributary gifts omitted. See Table 1 for tributary gifts units.

tiger skins, 100 folding fans (paeksŏn 白扇), and many stationery items such as the finest paper like a mirror (kyŏngmyŏnji 鏡面紙), high-quality white paper (paekmyŏnji 白綿紙), hwangmopil, inkstones (hwayŏn 畫硯), and genuine ink sticks (chinmuk 眞墨). These were added in large quantities, for example, 40 sheets of kyŏngmyŏnji, 400 sheets of paekmyŏnji, 
100 pieces of chinmuk, and 100 hwangmopil pens. ${ }^{41}$

The newly-added pangmul in 1593 have something in common. These are all main exports of state and private trade in the 16th century. This indicates that the Chosŏn court chose to compensate for the effects of wartime scarcity on pangmul by including its major commercial exports as tributary gifts. By examining which specific widely-stocked items were added to the 1593 pangmul, we can perhaps glimpse changes in the Chosŏn economic environment between 1430 and $1593 .{ }^{42}$ In this section, we will take a closer look at the newly added pangmul items after the Imjin War.

Finest Paper as a Mirror (kyŏngmyŏnji 鏡面紙) and High-Quality White Paper (paekmyŏnji 白綿紙)

Chosŏn's kyŏngmyŏnji paper is very fine, robust, smooth, and glossy. It was often used to print diplomatic documents. ${ }^{43}$ This paper was one of the most durable and finest among all paper produced in East Asia at the time; ${ }^{44}$ it carried a reputation that it could last for more than a thousand years. The softness of the paper was such that as a way of praising the sophistication of Chosŏn paper manufacturing technology, the Ming envoys would suggest that it was made of silkworm cocoons. ${ }^{45}$ The Ming Jiajing Emperor (嘉靖帝; r. 1521 1567) in particular enjoyed Chosŏn paper-several times he suggested ways to add paper, ${ }^{46}$ instead of

41 There is a study claiming that the kyŏngmyŏnji and the paekmyŏnji are the same (Jung Sunyoung, Research on paekmyŏnji, Bibliographic Research, 41, 2008), but this author disagrees. As shown in Table 2, the Chosŏn court sent the two separately.

42 Koo (2018).

43 Hagok Choch'ŏngi, Jun. 7, 1574.

44 Kim Hosŏk, et al. (2019).

45 Dong Yue (2012).

46 Chungjong Sillok 100:62b (May 8, 1543); Chungjong Sillok 100:63b (May 8, 1543); Chungjong Sillok, 100:73a (Jun. 10, 1543); Shizōng Shílù of Ming, 59:10 
hwamunsŏk, to the list of pangmul. In response, the Chosŏn court added 600-1,000 sheets of paper in the form of a "special gift" to prevent them from becoming a fixed item for regular envoys' pangmul. ${ }^{47}$ The Ming court gave 100 yang (兩) of silver and various kinds of silk as a gift in return for this paper each time it was sent. ${ }^{48}$ Records show that other Ming officials also requested this kind of paper. ${ }^{49}$ In short, as Chosŏn's material paper-making culture, technology, and production techniques deepened in the 16th century, Chosŏn paper was widely sought after by Ming Emperors, officials, and literati. Its reputation and popularity, therefore, made it a choice pangmul amid the scarcity brought on by the outbreak of the Imjin War, because it was popular, valuable, and already being produced.

\section{Folding Fans}

A folding fan is a folding fan with a featureless white background. The folding fan was made of sturdy Chosŏn paper and bamboo strips. At that time, the Chinese mainly used round fans that were not foldable, so they preferred Chosŏn's folding fan, which was small enough to fit in one's pocket. During the 16th century, these folding fans were actively exported to Ming China via state and private trade. Indeed, it was one of the most

\section{(Oct. 21, 1546).}

47 Chungjong Sillok, 100:64b (May 12, 1543); Chungjong Sillok, 100:77a (Jun. 29, 1543); Myŏngjong Sillok, 5:24b (Feb. 20, 1547).

48 Chungjong Sillok, 101:45b (Nov. 22, 1543); Shizōng Shílù of Ming, 59:35 (Jan. 17, 1547); Shìzōng Shílù of Ming, 60:24 (Jul. 24, 1547); Shìzōng Shílù of Ming, 69:96 (May 26, 1553); Myŏngjong Sillok,18:10a (Feb. 9, 1555); Shizōng Shílù of Ming, 73:09 (May 3, 1555); Myŏngjong Sillok, 18:64a (Jun. 16, 1555); Myŏngjong Sillok, 20:5b (Jan. 17, 1556).

49 Sŏngjong Sillok, 9:4b (Jan. 10, 1471); Sŏngjong Sillok, 17:2b (Apr. 9, 1472); Myŏngjong Sillok, 2:85b (Nov. 3, 1545); Myŏngjong Sillok, 19:6b (Jul. 14, 1555); Hagok Choch'ŏngi, Jun. 7, 1574. 
frequently-exported items of the 15 th century. ${ }^{50}$ The popularity of these folding fans and the volume with which they were traded indicates that the Chosŏn treasury likely had many on hand. Folding fans were added to the emperor's pangmul because they were a special product of Chosŏn, easy to procure, and in high demand from Ming.

\section{Hwangmopil, Hwayŏn, and Chinmuk}

As mentioned earlier, hwangmopil are writing brushes made of weasel hair. These brushes were strong, short-haired, and could give writing a sharp and fine expression. ${ }^{51}$ They were recognized for their excellence during the Koryŏ era, and Chosŏn intellectuals such as Chang Yu (張維; 1587 1638) and Yu Tŭkkong (柳得恭; 1748 1807) called them the finest brushes in the world. ${ }^{52}$ In the 15 th century, these brushes were designated as pangmul for the crown prince. They were added as pangmul for the Ming Emperor during the Imjin Wars, and were part of the Pangmul sent to the Emperor of the Qing in the late Chosŏn dynasty as well as exported by the thousands each year to Japan. Interestingly, the Qing Chinese had sold weasel hair to the Chosŏn dynasty but were unable to make hwangmopil themselves. ${ }^{53}$ Hwangmopil production expanded and grew during the 16th century as one of the "four treasures of study" (brush, ink, paper, and inkstones 文房四友).

Hwayŏn or inkstones were also a favorite item of Chinese bureaucrats. Chosŏn bureaucrats often presented inkstones to Ming envoys and bureaucrats as gifts or upon request. ${ }^{54}$ Even those who would not receive gifts from Chosŏn officials were willing to receive an inkstone from

50 Koo (2019).

51 Park Changseon (2020).

52 Jang Yu, Kyegokchip. fasc. 4, View; Yu Tŭkkong, Kyŏngdo Chapchi.

53 Lee Seungmin (2020).

54 Hoesanjip and Choch 'ónrok, Jul. 23, 1537; Chungjaejip and Choch'önrok, Oct. 28, 1539; Chungjaejip and Choch'onnrok, Nov. 4, 1539; Chungbongjip and Choch'ŏn Ilgi, Jul. 20, 1574; Hakpong Ilgo and Choch'ŏn Ilgi (Apr. 12, 1577). 
Chosŏn officials. ${ }^{55}$ Inkstones were exported to Ming China at high prices during the 16 th century. ${ }^{56}$

Chinmuk refers to an ink stick of high quality. Chosŏn chinmuk were usually yumaemuk (油煤墨), made from soot burned with oily animal or plant fats-perilla oil in this case. ${ }^{57}$ Songyŏnmuk (松煙墨) made from soot produced by burning pine trees, was also a representative ink stick in Chosŏn. However the Chinese seem to have preferred yumaemuk for its clear and glossy color, like oil-based ink. ${ }^{58}$ Even in the late Chosŏn dynasty, the government sent yumaemuk as a pangmul for the Qing (清) dynasty. ${ }^{59}$

In short, the Imjin Wars interrupted and changed the pangmul policies and practices that the Chosonn court had continued since 1430. It forced the Chosŏn dynasty to include popular trade items in pangmul because these were already being produced and, thus, could be procured more easily amid wartime scarcity. As such, the inclusion of these items indicates that production priorities in the Chosŏn era, centered around exporting the "four treasures of study," heavily influenced the composition of pangmul.

However, as Table 2 shows, the offerings of sŏngjŏlsa were not fixed. The composition of pangmul changed throughout the war. Let us take the following examples:

55 Hoesanjip and Choch'ǒnrok, Aug. 5, 1537; Chungjong Sillok, 90:32b (Apr. 13, 1539); Injong Sillok, 2:45a (May 4, 1545).

56 Chungbongjip and Choch'ŏn Ilgi, Aug. 3, 1574; Chungbongjip and Choch'ŏn Ilgi, Aug. 1574; Chungbongjip and Choch'ón Ilgi, Sept. 10, 1574.

57 Yi Sukwang, Chibong Yusŏl. Database of the Institute for the Translation of Korean Classics. https://db.itkc.or.kr/; Pok-yongbu and Kiyong.

58 Han Chiyun, Haedong Yǒksa and Mulsanji I.

59 Tongmunhwigo, additional version, fasc. 3, Sept. 17, 1638. Pangmulchŏn; Tongmunhwigo, original version, fasc. 49, pŏmwŏl 1, People of Our State, Jan. 22, 1653. Pangmulchu; Tongmunhwigo, original version, fasc. 41, Ch'ikyu, Jul. 20, 1679. Pangmulchŏn; Tongmunhwigo, original version, fasc. 48, border, Apr. 19, 1746. Pangmulpyo. 
(C-1) 20 pil of white ramie; 20 pil of myŏnju; 5 hwanghwasŏk; 5 manhwasŏk; 5 manhwabangsŏk; 5 ch'aehwasŏk; 30 kŭn of ginseng; 2 tiger skins; 2 leopard skins; 2 deer skins; 3 pieces of hwayŏn; 100 hwangmopil pens; 50 yumaemuk; 100 folding fans; 10 variegated colored horses. -- In 1596 (29th years of King of Sŏnjo's reign $)^{60}$

(C-2) 10 pil of white ramie; 20 pil of myŏnju; 2 yŏmseok; 5 manhwasŏk; 5 chapch'aehwasŏk; 30 kŭn of ginseng; 2 tiger skins; 2 leopard skins; 10 otter skins; 5 copies of thick oil paper (yŏllyuk huyuji 連陸厚油紙); 2 pieces of hwayŏn; 100 hwangmopil pens; 100 folding fans; 10 variegated colored horses. -- In 1597 (30th years of King of Sŏnjo's reign $)^{61}$

All of the sources in (C) are lists of items the tongjisa sends to the emperor. In (C-1), only myŏnju increased, but decreased for all pangmul in 1593. They were unable to prepare any paper. The year 1596 was the fifth year of the war, and it seems that the protracted war made it more difficult to secure goods. There are also slight differences between $(\mathrm{C}-1)$ and $(\mathrm{C}-2)$. For instance, there are more white ramie and otter skins in (C-2), and fewer mats. Yóllyuk huyuji, a type of paper, appeared in the list. In the early years of the Imjin Wars, kyŏngmyŏnji, which could be regarded as the finest kind, was sent as a tributary gift, but it was replaced with chŏmyukchang huyuij (粘六張厚油紙), yŏllyuk huyuji, and the like. ${ }^{62}$ The process for creating kyŏngmyŏnji was lengthy since it required a lot of time to tap the outside of the paper to soften the surface. It thus seems that

60 Sadaemun'gwe, fasc. 17, Tongihap'yo (Nov. 3, 1596).

61 Sadaemun'gwe, fasc. 22, Tongjihap'yo (Nov. 13, 1597).

62 Sadaemun'gwe, fasc. 22, Tongjihap'yo (Nov. 13, 1597); Sadaemun'gwe, fasc. 35, Sŏngjŏl'hapyo (Aug. 17, 1600); Sadaemun'gwe, fasc. 42, Sŏngjŏl'hapyo (Aug. 17, 1603); Sadaemun'gwe, fasc. 47, Tongjihap'yo (Nov. 23, 1606). 
it was subsequently replaced with thick oil paper (huyuji 厚油紙) ${ }^{63} \mathrm{~Pa}$ per was also consumed more heavily in Chosonn during the war (for example, in the making and wearing of paper clothes). ${ }^{64}$ Ultimately, it can be confirmed that there was a difference in the items that could be procured in each period, and that they increased or decreased accordingly.

\section{Pangmul after the Imjin Wars}

Table 3 gives us an idea of how pangmul practices for regular visiting envoys, sŏngjŏlsa and tongjisa, changed after the Imjin Wars as Chosŏn society regained stability.

The table shows that even after the end of the Imjin Wars, pangmul slightly varied rather than being firmly fixed. This is because the postwar recovery of Chosŏn society was greatly prolonged. From 1593 to 1603, yellow ramie and hemp almost disappeared. As mentioned, hemp had the status of official cloth (chŏngpo) in early 15th-century Chosŏn and was used as pangmul and an export. By the end of that century, cotton emerged as a real currency and its use in Chosŏn's domestic economy greatly decreased. Cotton was cultivated in three southern provinces (Ch'ungch'ŏng, Kyŏngsang, and Chŏlla), and hemp was produced in lessproductive northern provinces (such as P'yŏngan, Hamgyŏng, and Hwanghae). ${ }^{65}$ Through the 16th century, as the value and production of hemp declined, the amount of hemp in the Chosŏn government's possession also decreased. This led hemp to be excluded from the wartime pangmul lists.

63 Kim Hosŏk, et al. (2008).

64 Sŏnjo Silok 31:1b (Oct. 3, 1592).

65 Park Pyeongsik (2018); Cho Sangjun (2020). 
Table 3. List of Sŏngjŏlsa Pangmul for the Ming emperor (1600, 1603, and 1606).

\begin{tabular}{|c|c|c|c|c|c|}
\hline \multirow{2}{*}{$\begin{array}{l}\text { Type of } \\
\text { items }\end{array}$} & \multirow{2}{*}{ Pangmul Envoy } & \multirow{2}{*}{$\begin{array}{l}\text { Before the } \\
\text { Imjin Wars }\end{array}$} & \multicolumn{3}{|c|}{ After the Imjin Wars } \\
\hline & & & 1600 & 1603 & 1606 \\
\hline \multirow{6}{*}{ Textiles } & Yellow ramie & 10 & 0 & 10 & 10 \\
\hline & White ramie & 20 & 10 & 20 & 20 \\
\hline & Black hemp & 70 & 0 & 0 & 70 \\
\hline & Tabby silk & 10 & 0 & 0 & 0 \\
\hline & White tabby silk & 20 & 10 & 20 & 20 \\
\hline & Yellow tabby silk & 0 & 10 & 40 & 0 \\
\hline \multirow{5}{*}{ Mats } & Yŏmsŏk & 2 & 2 & 2 & 2 \\
\hline & Manhwasŏk & 0 & 5 & 0 & 0 \\
\hline & Manhwabangsŏk & 20 & 5 & 20 & 20 \\
\hline & Hwanghwasŏk & 20 & 5 & 20 & 20 \\
\hline & Ch'aehwasǒk & 20 & 5 & 20 & 20 \\
\hline Medicinal & Ginseng & 50 & 50 & 50 & 50 \\
\hline Horses & Horses & 40 & 10 & 20 & 20 \\
\hline \multirow{3}{*}{ Skins } & Leopard skin & 10 & 0 & 10 & 10 \\
\hline & Otter skin & 20 & 5 & 20 & 20 \\
\hline & Tiger skin & 0 & 2 & 0 & 0 \\
\hline Fans & Folding fan & 0 & 100 & 100 & 0 \\
\hline \multirow{4}{*}{ Stationery } & Chŏmyukchang huyuji & 0 & 10 & 8 & 10 \\
\hline & Hwangmopil & 0 & 100 & 0 & 0 \\
\hline & Hhwayŏn & 0 & 3 & 0 & 0 \\
\hline & Genuine ink stick & 0 & 50 & 0 & 0 \\
\hline
\end{tabular}

* Units of tributary gifts omitted. See Tables 1 and 2 for tributary gifts' units.

Sources: Sadaemun'gwe, fasc. 35, Sŏngjŏl'hapyo (聖節賀表) (Aug. 2, 1600); Sadaemun'gwe, fasc. 42, Sŏngjŏl'hapyo (聖節賀表) (Aug. 17，1603); Sadaemun'gwe fasc. 47, Sŏngjŏl’hapyo (聖節賀表) (Aug. 17, 1606).

However, the pangmul lists of 1606 practically became almost the same as those of the 15th and 16th centuries. About eight years after the war ended, the old practices were restored. Then we also need to look at tongjisa envoys' lists for the years 1605-1608 (Table 4). 
Table 4. List of Pangmul given by Dongjisa envoys to the Ming emperor (16051608).

\begin{tabular}{|c|c|c|c|c|c|c|}
\hline \multirow{2}{*}{$\begin{array}{l}\text { Type of } \\
\text { items }\end{array}$} & \multirow{2}{*}{ Pangmul Envoy } & \multirow{2}{*}{$\begin{array}{l}\text { Before the } \\
\text { Imjin Wars }\end{array}$} & \multicolumn{4}{|c|}{ After the Imjin Wars } \\
\hline & & & 1605 & 1606 & 1607 & 1608 \\
\hline \multirow{4}{*}{ Textiles } & Yellow ramie & 10 & 10 & 20 & 10 & 10 \\
\hline & White ramie & 20 & 20 & 20 & 20 & 20 \\
\hline & Black hemp & 40 & 40 & 30 & 40 & 40 \\
\hline & Муо̆пји & 20 & 20 & 0 & 20 & 20 \\
\hline \multirow{5}{*}{ Mats } & Yŏmsŏk & 0 & 2 & 0 & 2 & 2 \\
\hline & Manhwasŏk & 20 & 20 & 10 & 20 & 20 \\
\hline & Manhwabang-sŏk & 20 & 20 & 10 & 20 & 20 \\
\hline & Hwanghwasŏk & 20 & 20 & 10 & 20 & 20 \\
\hline & Chaehwasŏk & 20 & 20 & 10 & 20 & 20 \\
\hline Medicinal & Ginseng & 50 & 50 & 0 & 50 & 50 \\
\hline Horses & Hemp & 30 & 20 & 10 & 30 & 30 \\
\hline \multirow{3}{*}{ Skins } & Leopard skin & 10 & 10 & 0 & 10 & 10 \\
\hline & Otter skin & 0 & 0 & 0 & 0 & 0 \\
\hline & Tiger skin & 0 & 0 & 0 & 0 & 0 \\
\hline Fans & Folding fan & 0 & 0 & 100 & 0 & 0 \\
\hline \multirow{4}{*}{ Stationery } & Chŏmyukchang huyuji & 0 & 0 & 10 & 0 & 0 \\
\hline & Hwangmopil & 0 & 0 & 100 & 0 & 0 \\
\hline & Hhwayŏn & 0 & 0 & 3 & 0 & 0 \\
\hline & Yumae inkstick & 0 & 0 & 50 & 0 & 0 \\
\hline
\end{tabular}

Sources: Sadaemun'gwe, fasc. 45, Tongjihap'yo (冬至賀表) (Nov. 12, 1605); Sadaemun'gwe, fasc. 47, Tongjihap'yo (冬至賀表) (Nov. 23, 1606); Sadaemun'gwe, fasc. 48, Tongjihap'yo (冬至賀表) (Nov. 4, 1607); Sadaemun'gwe, fasc. 51, Tongjihap'yo (冬至賀表) (Nov. 15, 1608).

Table 4 indicates that the Chosŏn dynasty's economic recovery led to the restoration of its pre-war pangmul policies. However, there were a few differences between 1606 and pre-war pangmul. The 1606 lists did 
not include myŏnju and ginseng, and only half as many mats compared to pre-war levels were included. This shortfall was replaced with folding fans, paper, hwangmopil, hwayŏn, and chinmuk. The Chosŏn dynasty tended to adhere to old pangmul practices, but when it was difficult to prepare the old tributary items, it replaced these with popular items such as folding fans and stationery items.

All pangmul sent during the reign of King Injo (仁祖; r. 1623 1649) to the Ming (1623-1637) are not specified in available sources, but the patterns identified in Tables 3 and 4 seem to have persisted during this period. This is because white ramie, myŏnju, mats, folding fans, oil paper, leopard skins, and otter skins were being identified as pangmul during this period. ${ }^{66}$ The folding fans usually appeared as a substitutes for gifts to the Qing dynasty in the late Chosŏn period. ${ }^{67}$

It is noteworthy that folding fans still appear on the pangmul list of the reign of King Injo. This indicates the changing production and distribution of goods in the 17th-century Chosŏn dynasty and further suggests that it was difficult to replicate the composition of early 15th-century pangmul because of this changed economic focus and the lingering effects of the war. In addition, the Chosŏn court was able to make changes to the pangmul list in the 17 th century through the experience of flexibly preparing pangmul during the Imjin Wars.

\section{Conclusion}

This paper has traced how the composition and quantity of tributary gifts (pangmul 方物) sent by Chosŏn regular envoys to the Ming Emperor

66 Kwanghaegun Ilgi, 114:11b (Apr. 26, 1617); Sŭngjŏngwŏn ilgi, 56:85b (Feb. 28, 1637); Sŭngjŏngwŏn ilgi, 57:70a (Apr. 14, 1637); Sŭngjŏngwŏn ilgi, 57:108a (Apr. 21, 1637).

67 Man'giyoram, uses of property 5, Tributary Gifts, Annual Tributary Gifts, Winter Solstice. 
changed over time between the 15th and 17th centuries and examines the meanings of these changes. It has added to the literature by examining pangmul practices beyond the year 1430, showing the effects of the Imjin Wars on these practices, and proving that the quantities and compositions of these gifts were not fixed.

Pangmul conventions of the early Chosŏn period were a continuation of Koryŏ-era practices. However, as a response to the difficulty faced by his subjects to pay in gold and silver, King T'aejong and Sejong appealed to the Ming to allow the Chosŏn court to send specialty items as tribute instead of gold and silver. Since the 11th century, Koryŏ and Chosŏn have sent gold and silver as a gift to the Chinese dynasty. This practice was abolished after 400 years by the efforts of King Sejong of the Chosŏn dynasty in the 15th century. It, however, would reappear in the form of Annual Tributary Payments (歲幣) after the 1636 Qing (清) invasion of Chosŏn.

The composition of the pangmul also changed in 1430. The Chosŏn dynasty increased the quantity of hemp and Chosŏn specialty products such as mats, which were largely held in the government treasury at the time. Silk and horses were also added. Horses were expensive but procuring them was easier, as opposed to precious metal mining - the decision to exclude gold and silver from the pangmul list was not an economic one, but a response to the people's suffering. Of the existing pangmul items, leopard skin and otter skin, which were difficult to procure, were not added. The Chosŏn dynasty also decided to send yellow ramie, white ramie, hemp, myŏju, manhwasŏk, manhwabangsŏk, hwanghwasŏk, chaehwasŏk, ginseng, leopard skin, otter skin, and horses during this period, which continued into the 16th century when Japan invaded Chosŏn Korea during the Imjin Wars.

After the outbreak of the war, the Chosŏn court found it difficult to procure pangmul and included folding fans and new stationery items such as paper (kyŏngmyŏnji, paekmyŏnji, and oil paper), inkstones (hwayŏn), ink sticks (chinmuk and yumaemuk), writing brushes (weasel-tail hair) to compensate for the lack of conventional specialty items. This change also 
reflects changes in Chosŏn economic and social life, as these items were easily procurable and producible even in wartime. These were major trade (both official and private) and export items of the Chosŏn dynasty in the 16th century. Moreover, after 200 years since the founding of the dynasty, the inevitable change in the product mix of the 16th-century Chosŏn also influenced the Ming Emperor's tributary gifts.

After the war, as the Chosŏn dynasty regained stability, it attempted to replicate its earlier pangmul practices; however, it was unable to reproduce them exactly and went back and forth between the 15th century practices and the 17th century conditions. In short, this paper has demonstrated how Chosŏn pangmul to the Ming was relatively flexible, and that it both accounted for and reflected willing (technological, etc.) and unwilling (e.g., wartime scarcity) changes to economic circumstances.

\section{References}

Primary Sources

1. Chosŏn Wangjo Sillok 조선왕조실록 [the Veritable records of the Chosŏn dynasty]. Database of the National Institute of Korean History. http://sillok.history.go.kr

2. Tongmunhwigo 同文彙考 [Collection of Chosŏn's diplomatic documents]. In Hankuk Saryo Ch'ongsŏ 韓國史料叢書 [Collection of Korean Historical Materials] vol. 24. Seoul: Kuksap'yŏnch'an wiwŏnhoe 1978.

3. Shílù of Ming 明實錄 [the Veritable records of the Ming dynasty]. Database of the National Institute of Korean History. http://sillok.history.go.kr/mc/main.do.

4. Koryŏsa 高麗史 [History of the Koryŏ dynasty]. Database of the National Institute of Korean History. http://db.history.go.kr/KO REA/.

5. Kyŏngguk Taejŏn 經國大典 [The great code for the governance of the state]. Database of the National Institute of Korean History. 
http://db.history.go.kr/law/.

6. Eo, Sukkwŏn 魚叔權. Kosach'waryo 放事撮要 [Concise reference of historical facts]. Changsŏgak C15 2A.

7. Sadae mun'gwe 事大文軌 [Documents of serving the great]. In Chosŏn saryoch'onggan 朝鮮史料叢刊 [Collection of Korean Historical Materials], vol. 7. Seoul: Chosŏnsa p'yŏnsuhoe 1935.

8. Sŭngjŏngwŏn Ilgi 承政院日記 [Daily Records of the Royal Secretariat]. Database of the National Institute of Korean History. http://sjw.history.go.kr/main.do.

9. Shen, Shixing. Daming Huidian 大明會典 [Collected statutes of the Great Ming]. Shanghai: Shanghai guji chubanshe, 1995.

10. $\mathrm{Xu}, \mathrm{Pu}$. Daming Huidian 大明會典 [Collected statutes of the Great Ming]. Database of Sagojŏn'sŏ 四庫全書.

11. Kim, Sŏngil 金誠一. Hakpong Ilgo 鶴峯逸稿 [Collected works of Kim Sorngil]. Database of the Institute for the Translation of Korean Classics. https://db.itkc.or.kr/.

12. Xu, Jing 徐咕. Xuanhe Fengshi Gaoli Tujing 宣和奉使高麗圖經 [Xu Jing's travel journal to Goryeo]. Database of the Institute for the Translation of Korean Classics. https://db.itkc.or.kr/.

13. Hŏ, Bong 許等. Hagok Chochŏngi 荷谷朝天記 [Hŏ Bong's diary about traveling to the Ming]. Database of the Institute for the Translation of Korean Classics. https://db.itkc.or.kr/.

14. Chŏng, Hwan 丁煥. Hoesanjip 檜山集 [Collected works of Chŏng Hwan]. Database of the Institute for the Translation of Korean Classics. https://db.itkc.or.kr/.

15. Kwŏn, Bŏl 權橃. Chungjaejip 冲齋集 [Collected works of Kwŏn Bŏl]. Database of the Institute for the Translation of Korean Classics. https://db.itkc.or.kr/.

16. Cho, Hŏn 趙憲. Chungbongjip 重峯集 [Collected works of Cho Hŏn]. Database of the Institute for the Translation of Korean Classics. https://db.itkc.or.kr/.

17. Yi, Sukwang 李睟光. Chibong Yusŏl 芝峯類說 [Chosŏn's first encyclopedia, written by Yi Sukwang]. Database of the Institute for the 
Translation of Korean Classics. https://db.itkc.or.kr/.

18. Chang, $\mathrm{Yu}$, 張維. Kyegokchip 谿谷集 [Collected works of Chang $\mathrm{Yu}$ ] Database of the Institute for the Translation of Korean Classics. https://db.itkc.or.kr/.

19. Han, Ch'iyun 韓致㘤. Haedong Yǒksa 海東繹史 [Collection of Historical Records of the Korean Peninsula]. Database of the Institute for the Translation of Korean Classics. https://db.itkc.or.kr/.

20. Yu, Tŭkkong 柳得恭. Kyŏngdo Chapchi 京都雜誌 [Records of Life and Customs in Chosŏn].

Secondary Sources

21. Cho, Hyosook and Lee, Eunjin. "Kimhwakmyo ch'ult'o chingmul chejik t'ǔksŏng yŏn'gu" 김확묘 출토직물 제직 특성 연구 [A Study on the weaving characteristics of fabrics excavated in Kim Hwak tomb]. Journal of the Korean Society of Costume 61 (2) (2011).

22. Cho, Sangjun. "Chosŏnshidae sambe saengsanji yŏngu" 조선시대 삼 베 생산지 연구 [A Study on production sites of Sambe in the Chosŏn dynasty]. Institute of Human Sciences 66 (2020).

23. Dong Yue 董越. Chosŏnbu 朝鮮賦 in Sajoseolok 使朝鮮錄 III [Records of Dong Yue's visit to Chosŏn as envoy], trans. by Hankyu Kim. Seoul: Somyeong Publishing (2012).

24. Jeon, Hae-jong. "Ch'ŏngdae hanjung chogonggwan'gye chonggo" 청 대 한중 조공관계 종고(綜考) [A comprehensive study on the tribute relations between Korea and China in the Qing dynasty]. The ChinTan Society 29.30 (1966).

25. Jung, Donghun. “Koryŏ Kŏran Kŭm kwan'gye-esŏ 'chogong'-ŭi ŭimi” 고려-거란.금 관계에서 '조공'의 의미 [The Meaning of tribute in the Relations between Goryeo, Khitan, and Jin]. The Chin-Tan Society 131 (2018).

26. Jung, Donghun. “1260-70 nyŏndae koryŏ-monggol kwangye-eš̆ segong-ŭi ŭimi” 1260-70년대 고려-몽골 관계에서 歲貢의 의미 [The Meaning of annual tribute in the Goryeo-Mongol Relations in the 
1260-1270s], The Chin-Tan Society 134 (2020).

27. Jung, Sunyoung. "Paekmyŏnji-e gwanhan yŏn'gu” 백면지에 관한 연 구 [The Study for Bakmyun paper], Korean Society of Bibliography 41 (2008).

28. Kim, Hosŏk. Han'gug-ŭi chŏnt'ong hanji 한국의 전통 한지 [Traditional Korean paper]. Seoul: Sun Publishing, 2019.

29. Kim, Kujin. "Chosŏn chŏngi hanjung kwangyesa-ŭi shiron" 조선 전 기 한중관계사의 시론 [A study on the history of Korea-China relations in the early Chosonn dynasty]. Hongiksahak 4 (1990).

30. Kim, Soonja. “Yŏmalsŏnch'o-ŭi taemyŏng mamuyŏk” 麗末鮮初 對明 馬貿易 [Trade of horses with the Ming during the end of Goryeo and the early Chosŏn period]. In Structure and development of Korean history, Seoul: Hyean, 2000.

31. Kim, Sunghee. "Hwamunsŏk munyangdijain-ŭi hyŏndaejŏk chaegusŏng-e gwanhan yŏngu-Chosŏnjo ch'osanghwa-rŭl chungshimŭro" 화문석 문양디자인의 현대적 재구성에 관한 연구-조선조 초상화를 중심 으로 [A Study on the reconstruction of pattern design found in Hwamunseok: Focusing on the portraits of the Chosonn dynasty]. The Journal of the Korea Society of Art \& Design 20·3 (2017).

32. Koo, Doyoung. "Chosŏn ch'ogi taemyŏng muyŏkch'eje-ŭi sŏngnipgwa unyŏng" 조선 초기 대명무역체제의 성립과 운영 [The establishment and operation of the trade system with the Ming in the early Chosŏn period], The Historical Society of Korea 109 (2013).

33. Koo, Doyoung. Shibyuksegi hanjung muyŏk yŏn'gu 16세기 한중무역 연구 [Research on trade relations between Korea and China in the sixteenth century]. Seoul: T'aehaksa, 2018.

34. Koo, Doyoung. "Kŭnse tongashia segye yakyongshingmul insam-ui kagong-gwa yut'ong - Chosŏn-ŭi taemyŏng chinhŏn insam-ŭl chungshimŭro" 근세 동아시아세계 약용식물 인삼(人參)의 가공과 유통 -조선 의 대명(對明) 진헌인삼을 중심으로 [Processing and distribution of medicinal plant ginseng in early modern East Asia - Focusing on ginseng as a tribute item of Joseon to the Ming dynasty], The Korean Society for the History of Medicine 29 (3) (2020). 
35. Lee, Seungmin. "Chosŏnsan hwangmopil-ŭi saengsan-gwa ilbongwaŭi kyoyŏk" 조선산 黃毛筆의 생산과 일본과의 교역 [Production of hwangmopil in Chosŏn and its trade with Japan]. Korea-Japan Relations History Research 70 (2020).

36. Lee, Seungmin. "Chosŏnhugi kumu-rŭl t'onghaesŏ bon choil-gan mulpum kyoyŏk-ŭi hyŏnhwang-gwa t'ŭkjing” 조선후기 求貿를 통해 서 본 조·일간 물품교역의 현황과 특징 [Current status and characteristics of trade of goods between Korea and Japan through the late Chosŏn dynasty]. Dongguksahak 67 (2019).

37. Park, Pyeongsik. Chosŏn chŏn'gi taeoe muyŏk kwa hwap'ye yŏn'gu 조선 전기 대외무역과 화폐 연구 [Studies on the foreign trade and currency in the early Chosŏn dynasty]. Seoul: Chisik sanŏpsa, 2018.

38. Park, Pyeongsik. "Chosŏn chŏngi-ŭi insam chŏngchaek-gwa insamyutong” 조선 전기의 인삼정책과 인삼유통 [Ginseng policy and its distribution in the early Chosŏn dynasty]. The Journal of Korean History 143 (2008).

39. Shin, Sŏkho. "Chosŏn wangjo kaeguk tangshi-ŭi taemyŏng kwangye" 조선왕조 개국당시의 대명관계 [Chosŏn-Ming relations during the founding of the Chosŏn dynasty]. General Affairs in Korean History 1 (1959).

40. Sim, Yeonok and Jongsuk Keum, "Urinara-wa chungguk myŏngdaeŭi chikmul kyoryu yŏn'gu I” 우리나라와 중국 명대의 직물 교류 연구 I [Study on textile exchange of Korea and the Ming dynasty of China I]. Journal of Korean Traditional Costume 16 (2) (2013).

41. Yoo, Seungjoo. "Chosŏn chŏngi taemyŏng muyŏk-i kungnae sanŏb-e mich'in yŏnghyang” 조선 전기 對明貿易이 국내산업에 미친 영향 [The effects of the trade between Chosŏn and the Ming dynasty on the domestic industry in the early Chosŏn dynasty]. The Journal of Asiatic Studies 82 (1989). 


\section{Items of Tributary Gifts (Pangmul 方物) Sent to the Ming Dynasty by Chosŏn and their Changing Trends}

This paper examines changes and trends in tributary gifts (pangmul 方 物) sent by Chosŏn regular envoys to the Ming Emperor during the 15th and 17 th centuries.

First, pangmul items sent by the Chosŏn to the Ming were partially inherited from the Koryŏ era. Second, it examines how King Sejong's 1429 request that the Chosonn court pay its tribute by means other than gold and silver led the court to offer specialty goods as tribute instead of precious metals. It then moves on to explore how economic scarcity resulting from the Imjin Wars of 1592 led Chosŏn pangmul to be composed mostly of folding fans and stationery items such as paper (kyŏngmyŏnji, paekmyŏnji, and oil paper), inkstones (hwayŏn), ink (chinmuk and yumaemuk) and writing brushes (hwangmopil)-the dynasty's common, major export goods. After the war, the Chosŏn dynasty regained stability and returned to its pre-war pangmul practices. However, the pangmul were not completely fixed and showed tentative patterns, going back and forth between the practices of the 15 th century and the new circumstances of the 17th century.

In short, this paper explores how pangmul practices were not completely fixed, and how contingencies such as the war and the changing landscape of manufacturing in 16th-century Korea influenced the composition of Chosŏn pangmul.

Keywords: pangmul, Chosŏn, Ming, tributary relations, gift, paper, folding fan 
〈국문초록〉

\section{조선에서 명에 보낸 방물의 물목과 그 경향의 변화}

구도영 (동북아역사재단)

이 글은 15 17세기 동안 조선이 명 황제에 보냈던 정기사행의 방물과 그 수량이 시 기별로 어떻게 달라졌는지 추적하고, 그 의미를 살펴본 글이다.

국초 조선이 명에 보낸 방물은 고려-명의 방물을 일부분 계승했다. 조선 백성들이 金銀 납부의 고역을 호소하자, 세종은 明에 金銀 면제를 요청했고, 1429년 방물 구성 이 변화하게 된다. 조선 조정은 당시 국고에 넉넉하게 보유하고 있는 마포와 특산품인 席의 수량을 늘리고, 紬와 말을 새로 추가했다. 구하기 어려운 표피, 달피는 추가하지 않았고, 인삼과 황모필은 황태자에게만 추가했다. 1430 년에 정해진 방물이 16 세기에도 계속되었다.

정기사행의 방물은 1592 년 임진왜란으로 다시 변경되었다. 전쟁으로 방물 마련이 여 의치 않자, 조선은 전시 상황에서 보다 쉽게 확보할 수 있는 물건을 방물로 선택했다. 기존 방물은 수량이 감소했고, 쥘부채(摺扇)와 종이(鏡面紙, 白綿紙, 油紙), 벼루(畫硯), 먹(兴墨, 油煤墨), 붓(黃毛筆) 등 문방구가 새롭게 황제의 방물로 추가되었다. 주목할 점은 이 물건들이 16 세기 조선의 주요 수출품이었다는 점이다. 건국 후 약 200 년이 지 나며, 16세기 조선의 변화된 상품 생산 지형도가 황제 방물에도 영향을 준 것이다. 조 선은 전쟁이 끝나고 안정을 찾으면서, 조선 초에 설계된 방물 관행으로 돌아가는 모습 을 보였다. 하지만 온전하게 고정되지 않고, 15 세기의 관행과 17 세기의 여건을 오가며 유동적인 모습을 보였다.

조선은 방물의 관행을 준수하고자 하는 원칙 하에, 조선 백성의 폐해를 고려하고, 조 선의 경제적 변화와 여건을 반영하며 시기에 따라 융통성을 보였다.

주제어: 방물(方物), 조선(朝鮮), 명(明), 조공관계, 선물, 종이, 접선(摺扇) 